\title{
判別関数による心電図診断法の研究， 殊に左室肥大の鑑別について
}

\author{
日本医科大学第一内科学教室 (指䆃: 木村栄一教授) \\ 大学院学生 早川弘一 \\ Hirokazu Hayakawa
}

1. 判別関数作成の資料とした症例の判別成績

2. 判別関数作成の資料としなかつた症例の判別成綨

IV 各計測項目が判別に寄与する程度の検討

$\mathrm{V}$ 考察

1. 対象症例のえらび方について

2. 諸家の作成せる判別関数の批判

3. 著者の判別関数について

4. 著者の判別関数による判別成績について

(a) 判別関数作成資料とした症例の判別成績

(b) 判別関数作成資料としなかつた症例の判別成紸 に関して

5. 判別関数の各項目が判別に夸与する程展について

(a) 判別寄与程度の判定法の検討

(b) 各羘の判別に大きく奇与寸る計測項目について

i ）正常と高血圧の判別について

ii）正常と大動脈弁閉鎖不全の判別:ついて

iii）高血圧と大動脈弁閉鎖不全の判別について

6. 心電図判読詇理の問題点々将来

VI 結

論

\section{I 緒}

言

医師が通常行なつている心電図の診断は次の2つの 過程に分けて考えることができる。その1は，心電図 の各㑲波を識別して，その波の高さ，巾，曲線の勾配 などを計算する識別計測過程であり，その 2 は、諸計 測值を総合して心電図誩断を行なう判読過程である。 しかし計測過程では人間の目による誤差により, 判読 過程では医師の経験，主観の差異により，同じ症例に ついても人によつて讋断が異なる場合があり，また同
一人ですら日によつて異なる診断を下すことがある。

この医師の経験や主観の差を谁けるため, 診断過程 のすべてを機械化，自動化することが考学られる。こ の際, 人間の能力をはるか忆越光た記憶, 演算能力を 有する電子計算機の利用が当然考慮される。

電子計算機を利用するには，ます心電図の診断過程 の論理を機械に叔ぼえさせる必要がある。識別計測過 程の自動化に関しては, 关の論理を比較的簡単飞数学 的に処理できるため，すでにかなりの報告がなされて お放 ${ }^{1) \sim 9}$ ，Digital 計算機を利用寸る方式は，むはや 実用化の段階に入りつつ离る。

これに反し、判読過程の自動化はまだ注とんど実用 化されていない。その理由は，機械汇教光こむべき判 読論理去のものが，まだ十分完成されていないからで ある。現在の判読論理によると, 心筋硬塞, 脚ブロッ ク, WPW 症侯群, 低 $\mathrm{K}$ 血症, 高 $\mathrm{K}$ 血症, 不整脈な ぞは比軹的明確な䛦断基準により䛦断されるが，これ らは心電図彭断の対象となる所見のごく一部にすぎな い。

多くの心霓図所見はもつとむいまいな基準により彰

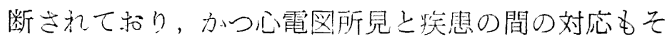
う密接でない。たとうば左室肥大の埻断に広く用いら れるSokolov \& Lyon ${ }^{10}$ の基準は，いくつかの項目上 りなつているが，その適中率は $85 \%$ にとどまるとさ れ ${ }^{11)}$ ，かなり高い偽陽性率と膤陰性率を避けることが できない212。

また僧帽性 P僧帽并狭窄の特徽的所見の一つとさ れるが，すべての僧帽弁狭窄が僧帽性 $\mathrm{P}$ を呈するわけ ではなく，また僧帽性 Pを示寸例がすべて僧帽弁㹨窄 であるわけではない。

すなわち, 心電図診断はいわば統計的, 確率的なる のであり、したがって各人がそれまで経験した症例の 集積により，その誂断は左古される。万人を納得させ る判読論理がま忘作られていないのはそのためでめ 
る。

しかし上述のように，かかる医師の経験や主観の差 異による誩断の差を避けるために，電子計算機による 自動判読方式を実現しようとすれば，どうしても普遍 罗当性のある判読論理を作らななければならない。

今，これ関する研究を文献飞徽するに，まず Arbeit ${ }^{13)}$ 促, 来の判読方式の 2 進法, 3 進法ないし それ以上飞よる整理を試みたが，更飞木村 ${ }^{14315}$ らはこ れを整理体系化するとともに，その機械化を行ない， 心電図学初歩の者でも,これを用いれば迅速かつ正碓 に心電図殓断を行ないらる方式を開発した。

また Stark, 岡島 $ら^{3 / 4)}$ 怯, Multiple adaptive matched filter 法により,また Young $ら^{16)}$ は線型多次 元再帰関数により，心電図パタンを新たな見地より分 類しようと試みている。

他方, 木村ら ${ }^{17) 18199}$ は Bayes の確率定理, 扔よび 尤度を用いて, また Rikli ら ${ }^{20}$ 拓よび他の研究者 達 $\left.{ }^{21}{ }^{22}{ }^{23}{ }^{221}\right)^{25}$ / 判別関数を用いて, 心電図と疾患の対 応の発見に努力している。これらの研究はいずれもか なり優秀な成果を哧さめえたと報告している。

以上の方法のうち判別関数は, 1936 年Fisher ${ }^{26}{ }^{27}$ 27 28) そより，重みづけされた幾種類かの測定值に基いて， 2つの異なる群を最るよく分類する方式として発表さ れたもので, その後 $\mathrm{Rao}^{27}$ らに上り, 肝疾患の分 類, 神経症類似疾患の判別なぞ臨床医学の問題にも応 用され，かなりの成果をあげた。我が国では，1952年 鳥居, 高橋 ${ }^{29}$ が肝疾息群の判別にこの方法を試みて いる。

しかし，判別関数が心電図診断に試みられた歴史は まだ浅く，したがつて発表された論文も現在のところ そう多くはない。前述の如く, 1961 年 Rikli $5^{20)}$ が 正常, 高血圧性左室肥大括上び大動脈弁閉塞不全飞よ る左室肥大の 3 群の判別に, また同年 Cady ら $^{21}$ が 正常と左室肥大の判別氏それぞれ試みたのがはじめと みられる。次いで 1962 年 Caceres ら ${ }^{22)}$ が肺動脈狭 窄と動脈管開存の判別のために判別関数を作成した。

1963 年には木村 ${ }^{23)}$ が Rikli らと同じ筷㭧群の判 別を Rikli らとやや異なつた方式で試みた。この報 告が，我が国で心雷図診断洋判別関数を忘用した最初 のものである。その後, 岡島, 安井ら ${ }^{24}$ が 1964 年に 正常, 左室肥大拓上び右室肥大の判別に, また Rees

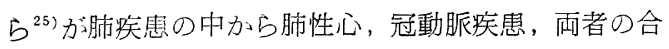
併しているもの，招上びそれ以外のものの 4 群を心電 図のみより鑑別する手段として，判別関数を用いてい
る。

心電図診断の立場よりみて, 以上の報皆を次の $2 つ$ に分類することができる。その 1 は左室肥大，右室肥 大などのごとき心電図に拈ける診断単位を求めるもの であり ${ }^{2124)}$, その 2 は心霞図上り直接病名を求めるも の2022223)25) である。

著者は，心電図鑑別診断に扔外る判別関数の有用性 を検討するとともに，その結果にもとづき，現在扔こ なわれている心電図判読法を批判検討する目的で，以 下の研究を企てた。研究対象として, 心電図䛦断上, 臨床的に最も重要とされる左室肥大, 寸なわち高血圧 招よび大動脈弁閉塞不全老えらんだ。

$$
\text { II 方法 }
$$

\section{1. 対象症例}

昭和 37 年1月から同年 11 月までの 11 カ月間に 日本医大附属病院内科治いて初診した年令 31 才上 り 64 才までの高血圧 47 例招上び 34 才上り 41 才 までの大動脈弁開鎖不全 3 例の全例老対象とした。な 扣この期間に来院し, 心電図検查を受けたが, 循環器 系をらくさ主要藏器に異常なしと判断された 26 才上 り 64 才までの 30 例を正常対照として用いた。全例 を対象とした理由は，疾㭧の頻度 (事前確率) をる考 慮すべきか否かを検討するためである。ただし，大動 脈并閉鎖不全は症例数があまりに少なく，測定值のか たよる扔それが岕るため，上記期間外の 16 例（16〜 82 才) を追加した。

高血圧としては, 収縮期圧 $160 \mathrm{mmHg}$ 以上, 拡張 期圧 $95 \mathrm{mmHg}$ 以上のもののみを用いた。大動脈升 閏鎖不全の診断は，心音図，心電図，血圧、胸部 $\mathrm{X}$ 線 写真, その他の臨床所見から決定した。両聅患とも, 典型的な左室肥大心電図を示さない症例をも含を。

以上の症例を資料として判別関数学作成し，それを 用いて，上記症例招上び上記症例以外の症例にっいて の判別成績を検討した。後者としては, 上記期間外の 正常 20 例 (17 58 才), 高血圧 20 例 (38〜77 才) 招上び大動脈弁開鎖不全 15 例（17 70 才）学対象 とした。

\section{2. 使用誘導}

理想的には，12 誘導全部についての情報を用いる べきであるが, 全誘導につき, それぞれの波高值, 時 間值を計測するのは龙大な時間を必要とする。それ故 左室肥大汇関する情報を最も多くふくむとみなされる $V_{5}$ 誘導のみ対象とした。

3. 対象心電図所見 
$-40-(80)$

表1に示す13 個の所見を光らんだ。これらは1誘 導につき侤えられる計測値の将とんどすべてを網羅す る。

\section{装 1 封像心電图所見と天の变挨}

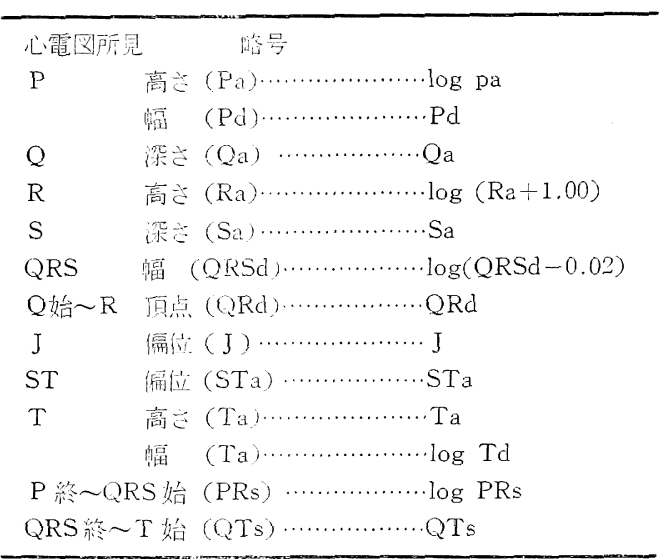

本表に用いた記号の中には, 常用の記号とその意味 を異にするものがある。たと充ば，Paのaは高さ (amplitude) または偏位度 (deviation) などの笔位值 を示し，羊た $\mathrm{Pd} の \mathrm{~d}$ は巾 (duration) あるいは間 隔 (interval) などの㭙間值走示。PRsのsは Segment趇わし，P の終りからＱRS の始めまで の時間值指す。QTsは QRS の終りから，Tの始 めまでの Segmentである。ST 偏位はJ (junction) より 0.04 秒むとに地いて計測した。

4. 判別関数の作成

判別関数は，てれぞれの個体についていくつかの計 測值がある場合，これらの計測值にそれぞれ重みづけ を行ない、これら老加算して得られる得点の大小によ
つて，個体の分類を行なう統計学的方法である ${ }^{27)^{301}}$ 。 この際, 計測值の重齐, 寸なわち判別係数は, 分類さ れるべき各群の得点の平均值の差が最大となるよう“ いいかえれば，各群閴の判別が最も良く行なわれるよ うな数学的条件によつて求められる

本論文の対象とする高血圧, 大動脈升閉鎖不全, 正 常対照の3 群に関する判別関数走作成するに当り，3 群を同時に判别する式を作成することは不可能ではな いが，繁杂隹な計算を要し，かつ判別能力は落ちる。そ れ故、これら3群のうち，2群ずつをそれぞれ判別す る式（すなわち正常と高盂圧, 正常と大動脈弁閉鎖不 全，高血圧と大動脈升閒鎖不全）在作成した。

ここで判別関数作成の計算過程支具体的力つ簡単に 述べる。一般に判別関数引゙適用されるのは, 多次元の 正規分布をなす連続量であるが，著者の朋いた心電図 所見の中には正規分布定示さないるのがある。去れ故 これら表1飞示如く，邀当な方法により近似的な 正規分布とするように変換を行なつた。

正常対照 (C) と高血压 (H) の場合を例にとると 各群の 13 項目の計測值の平均値を求め, 次にC群と $\mathrm{H}$ 群の各項目の平均値の差 $\mathrm{d}_{1}, \mathrm{~d}_{2} \cdots \cdots \cdots, \mathrm{d}_{13}$ 点求め る(表2)。次いで, それぞれの群内の計测項目間の 共分散 S(あるいは相関係数) 定計算する 表 $3 ， 4$, 5)。13 項目の中, $\mathrm{i}$ 番目と $\mathrm{j}$ 番目の計測項目につい て求めた共分散を Sij で表わし、C群でのそれを Sij $\mathrm{C}, \mathrm{H}$ 群でのそ扎在 Sij $\mathrm{H}$ と表秃して，

$$
\mathrm{Wij}=(\mathrm{Sij} \mathrm{C}+\mathrm{Sij} \mathrm{H}) / \mathrm{NC}+\mathrm{NH}-2
$$

なる睹を計算する。ただし、NCはC 群の、NHは H 群の症例数を表わす。

袁 2 各疾患群における測定值の平均之準標偏差

\begin{tabular}{|c|c|c|c|c|c|c|}
\hline & \multicolumn{2}{|l|}{ 正 } & \multicolumn{2}{|c|}{ 高 血 圧 } & \multicolumn{2}{|c|}{ 大勁脈并閉鎖不全 } \\
\hline & 平均 & 標蕉偏差 & 平均 & 標集偏差 & 平均 & 標準偏差 \\
\hline $\log \mathrm{pa}$ & -1.3846 & 0.2181 & -1.3231 & 0.2490 & -1.2851 & 0.2498 \\
\hline $\mathrm{Qa}$ & 0.0527 & 0.0953 & 0.0623 & 0.1150 & 0.1226 & 0.2492 \\
\hline $\log (\mathrm{Ra}+1.00)$ & 0.4587 & 0.1028 & 0.5617 & 0.1531 & 0.9766 & 0.2162 \\
\hline $\mathrm{Sa}$ & 0.3580 & 0.3720 & 0.5236 & 0.5431 & 0.5058 & 0.5273 \\
\hline $\mathrm{Ta}$ & 0.6153 & 0.2317 & 0.4228 & 0.3558 & 0.2247 & 0.8349 \\
\hline $\mathrm{J}$ & 0.0097 & 0.0398 & -0.0117 & 0.0710 & 0.0089 & 0.0777 \\
\hline $\mathrm{STa}$ & 0.0447 & 0.0593 & 0.0140 & 0.0480 & 0.0089 & 0.0777 \\
\hline $\mathrm{Pd}$ & 0.0777 & 0.0272 & 0.0789 & 0.0254 & 0.0953 & 0.0219 \\
\hline $\log (\mathrm{QRS}-0.02)$ & -1.3393 & 0.1361 & -1.3246 & 0.1531 & -1.2379 & 0.1466 \\
\hline QRd & 0.0260 & 0.0071 & 0.0249 & 0.0096 & 0.0311 & 0.0079 \\
\hline $\log \mathrm{Td}$ & -0.6902 & 0.1012 & -0.7489 & 0.2042 & -0.7602 & 0.1369 \\
\hline $\log$ PRs & -1.0787 & 0.2028 & -1.0927 & $0 .[751$ & -1.2100 & 0.1580 \\
\hline QTs & 0.1740 & 0.0831 & 0.2119 & 0.0545 & 0.2421 & 0.0382 \\
\hline
\end{tabular}


以上の值から 13 項目のそれぞれの判別係数 $\mathrm{b}_{1}, \mathrm{~b}_{2}$, $\cdots \cdots \cdot \mathrm{b}_{13}$ 求めるには, 次の 13 元 1 次連立方程式 を $\mathrm{b}_{1}, \mathrm{~b}_{2}, \cdots \cdots \cdots \mathrm{b}_{13}$ そついて解けばよい。

13 元 1 次連立方程式

$$
\begin{aligned}
& W_{11} b_{1}+W_{21} b_{2}+\cdots \cdots \cdots+W_{131} b_{13}=d_{1} \\
& W_{12} b_{1}+W_{22} b_{2}+\cdots \cdots \cdots+W_{132} b_{13}=d_{2}
\end{aligned}
$$

$W_{113} b_{1}+W_{213} b_{2}+\cdots \cdots \cdots W_{1313} b_{13}=d_{13}$

しかし，以上の計算を人間の手で行なうとすると龙 大な時間を必要とするので，IBM のデータ・センタ 一飞依頼し，IBM 7090 を使用して計算を行なつた。
以上により次の 3 種の判別関数を得た。

$\mathrm{F} 1$ (正常一高血圧) $=0.012 \log \mathrm{Pa}-0.905 \mathrm{Qa}-$ $4.965 \log (\mathrm{Ra}+1)-1.328 \mathrm{Sa}+1.167 \mathrm{Ta}+.0972 \mathrm{Ja}+$ $7.213 \mathrm{STa}-4.146 \mathrm{Pd}+1.070 \mathrm{log} .(\mathrm{QRSd}-0.02)+13$. $464 \mathrm{QRd}+2.465 \mathrm{Tp}+1.987 \mathrm{PRs}-3.705 \mathrm{QTs}+8.416$ $(-0.195)$

F 2(正常一大動脈升閍鎖不全) $=-2.597 \log \mathrm{Pa}-2.277$ $\mathrm{Qa}-3.143 \log (\mathrm{Ra}+1)-0.762 \mathrm{Sa}+3.081 \mathrm{Ta}-6.344$ $\mathrm{Ja}+5.919 \mathrm{STa}-3.765 \mathrm{Pd}-0.161 \log (\mathrm{QRSd}-0.02)$ $+20.624 \mathrm{QRd}-0.025 \mathrm{Td}+1.981 \mathrm{PRs}-4.687 \mathrm{QTs}-0$. $096(+0.198)$

F $3($ 高血圧一大動脈我閉鎖不全 $)=-0.842 \log \mathrm{Pa}$ $-1.978 \mathrm{Qa}-0.0688 \log (\mathrm{Ra}+1)+0.047 \mathrm{Sa}+1.814$

\begin{tabular}{|c|c|c|c|c|c|c|c|c|c|c|c|c|c|}
\hline & $\log \mathrm{Pa}$ & $Q$ & $\begin{array}{c}\log (\mathrm{Ra} \\
+1.00)\end{array}$ & $\mathrm{Sa}$ & $\mathrm{Ta}$ & $J$ & STa & $\mathrm{Pd}$ & \begin{tabular}{|l|}
$\log$ \\
$(\mathrm{QRSd}$ \\
$-0.02)$ \\
\end{tabular} & QRd & $\log \mathrm{Td}$ & $\log \mathrm{PRs}$ & QTs \\
\hline $\log \mathrm{Pa}$ & 1.000 & & & & & & & & & & & & \\
\hline $\mathrm{Qa}$ & -0.133 & 1.000 & & & & & & & & & & & \\
\hline $\begin{array}{c}\log (\mathrm{Ra} \\
+1.00)\end{array}$ & 0.056 & 0.262 & 1.000 & & & & & & & & & & \\
\hline $\mathrm{Sa}$ & 0.270 & -0.190 & -0.205 & 1.000 & & & & & & & & & \\
\hline $\mathrm{Ta}$ & 0.000 & -0.174 & 0.009 & -0.082 & 1.000 & & & & & & & & \\
\hline $\mathrm{J}$ & -0.114 & -0.274 & 0.066 & -0.173 & 0.535 & 1.000 & & & & & & & \\
\hline $\mathrm{STa}$ & -0.147 & $0 \cdot 301$ & -0.048 & 0.158 & 0.086 & 0.016 & 1.000 & & & & & & \\
\hline $\mathrm{Pd}$ & 0.333 & -0.374 & -0.318 & 0.151 & 0.355 & 0.445 & -0.080 & 1.000 & & & & & \\
\hline $\begin{array}{l}\log \\
(Q R S d \\
-0.02)\end{array}$ & 0.324 & 0.078 & -0.177 & 0.373 & 0.187 & -0.123 & 0.211 & 0.225 & 1.000 & & & & \\
\hline QRd & -0.025 & 0.448 & 0.029 & -0.014 & -0.310 & -0.482 & 0.150 & -0.379 & 0.261 & 1.000 & & & \\
\hline $\log \mathrm{Td}$ & -0.197 & -0.076 & 0.034 & 0.253 & -0.041 & -0.099 & -0.038 & -0.018 & -0.123 & -0.095 & 1.000 & & \\
\hline $\log$ PRs & 0.212 & 0.072 & 0.351 & 0.044 & -0.183 & -0.231 & -0.124 & -0.319 & -0.186 & 0.300 & -0.152 & 1.000 & \\
\hline QTs & 0.165 & 0.101 & 0.187 & 0.056 & -0.161 & -0.024 & -0.293 & -0.023 & 0.059 & 0.075 & -0.145 & 0.251 & 1.000 \\
\hline
\end{tabular}

表 3 高血圧における測定值相互間の相関係数

\begin{tabular}{|c|c|c|c|c|c|c|c|c|c|c|c|c|c|}
\hline & $\log \mathrm{Pa}$ & Q & $\left|\begin{array}{c}\log (\mathrm{Ra} \\
+1.00)\end{array}\right|$ & Sa & $\mathrm{Ta}$ & $\mathrm{J}$ & $\mathrm{STa}$ & $\mathrm{Pd}$ & $\begin{array}{l}\log \\
(\mathrm{QRSd} \\
-0.02) \\
\end{array}$ & QRd & $\log \mathrm{Td}$ & $\log$ PRs & QTs \\
\hline $\log \mathrm{Pa}$ & 1.000 & & & & & & & & & & & & \\
\hline $\mathrm{Qa}$ & -0.388 & 1.000 & & & & & & & & & & & \\
\hline $\begin{array}{r}\log (\mathrm{Ra} \\
+1.00)\end{array}$ & -0.396 & 0.468 & 1.000 & & & & & & & & & & \\
\hline $\mathrm{Sa}$ & 0.330 & -0.358 & -0.211 & 1.000 & & & & & & & & & \\
\hline $\mathrm{Ta}$ & -0.038 & 0.487 & 0.387 & -0.096 & 1.000 & & & & & & & & \\
\hline $\mathrm{J}$ & 0.233 & -0.171 & -0.456 & 0.128 & -0.170 & 1.000 & & & & & & & \\
\hline $\mathrm{STa}$ & 0.233 & -0.171 & -0.456 & 0.128 & -0.170 & 1.000 & 0.000 & & & & & & \\
\hline $\mathrm{Pd}$ & -0.056 & 0.051 & -0.029 & 0.256 & -0.149 & -0.031 & -0.031 & 1.000 & & & & & \\
\hline $\begin{array}{l}\log \\
(Q R S d \\
-0.02)\end{array}$ & 0.151 & -0.099 & 0.007 & 0.511 & -0.081 & 0.060 & 0.060 & 0.343 & 1.000 & & & & \\
\hline QRd & 0.227 & -0.103 & -0.322 & 0.094 & -0.120 & -0.144 & -0.144 & -0.063 & 0.385 & 1.000 & & & \\
\hline $\log \mathrm{Td}$ & -0.311 & -0.326 & -0.109 & 0.129 & -0.321 & 0.087 & 0.087 & 0.189 & -0.291 & -0.036 & 1.000 & & \\
\hline $\log \mathrm{PRs}$ & 0.533 & -0.339 & -0.405 & 0.421 & -0.202 & -0.053 & 0.053 & -0.129 & 0.132 & 0.170 & -0.152 & 1.000 & \\
\hline QTs & -0.148 & 0.075 & 0.465 & 0.225 & 0.065 & -0.186 & -0.186 & 0.283 & 0.457 & 0.290 & 0.206 & -0.014 & 1.000 \\
\hline
\end{tabular}

表 4 大動脈并閉鎖不全における測定值相互間の相閏係数 
表 5 正常におるけ测定値相互間の相関䌽数

\begin{tabular}{|c|c|c|c|c|c|c|c|c|c|c|c|c|c|}
\hline & $\log \mathrm{Pa}$ & $Q$ & $\mid \begin{array}{c}\log (\mathrm{Ra} \\
+1.00)\end{array}$ & Sa & Ta & $J$ & $\mathrm{STa}$ & $\mathrm{Pd}$ & $\begin{array}{l}\log \\
(\mathrm{QRSd} \\
-0.02) \\
\end{array}$ & QRd & $\log \mathrm{Td}$ & $\log$ PRs & QTs \\
\hline $\log \mathrm{Pa}$ & 1.000 & & & & & & & & & & & & \\
\hline $\mathrm{Qa}$ & -0.253 & 1.000 & & & & & & & & & & & \\
\hline $\begin{array}{r}\log (\mathrm{Ra} \\
+1.00)\end{array}$ & 0.072 & 0.124 & 1.000 & & & & & & & & & & \\
\hline $\mathrm{Sa}$ & 0.325 & -0.290 & -0.009 & 1.000 & & & & & & & & & \\
\hline $\mathrm{Ta}$ & 0.254 & -0.154 & 0.353 & 0.303 & 1.000 & & & & & & & & \\
\hline $\mathrm{J}$ & 0.174 & 0.506 & 0.080 & 0.074 & 0.252 & 1.000 & & & & & & & \\
\hline STa & 0.260 & 0.026 & 0.006 & 0.717 & 0.461 & 0.404 & 1.000 & & & & & & \\
\hline $\mathrm{Pp}$ & 0.020 & -0.141 & 0.019 & 0.241 & -0.164 & -0.152 & 0.122 & 1.000 & & & & & \\
\hline $\begin{array}{l}\log \\
(Q R S d \\
-0.02)\end{array}$ & -0.008 & 0.056 & 0.016 & 0.442 & 0.038 & -0.130 & 0.129 & 0.185 & 1.000 & & & & \\
\hline QRd & 0.240 & 0.389 & -0.079 & 0.015 & -0.009 & 0.278 & 0.210 & 0.007 & -0.061 & 1.000 & & & \\
\hline $\log \mathrm{Td}$ & 0.017 & -0.109 & 0.211 & 0.369 & 0.563 & 0.230 & 0.426 & -0.222 & 0.246 & -0.002 & 1.000 & & \\
\hline $\log$ PRs & 0.188 & -0.256 & -0.053 & -0.025 & -0.160 & -0.203 & -0.023 & -0.145 & -0.149 & -0.300 & 0.117 & 1.000 & \\
\hline QTs & 0.072 & 0.218 & -0.113 & -0.170 & -0.009 & -0.107 & -0.288 & 0.217 & 0.222 & -0.035 & 0.158 & -0.040 & 1.000 \\
\hline
\end{tabular}

$\mathrm{Ta}-9.450 \mathrm{Ja}+6.302 \mathrm{STa}-13.788 \mathrm{Pd}-1.198 \mathrm{log}$ (QRSd-0.02)-67.642 QRd-0.617 Td+3.276 PRs $-3.684 Q T s+4.480(+0.393)$

F 1 式は正常と高血圧, F 2 式忹正常と大動脈弁閉 鎖不全，F3 式は高血圧と大動脈弁閉鎖不全を，それ ぞれ判別する判別関数である。

これらの式に個々の症例の測定値を代入すると判別 得点が得られる。本論文の判別関数では, いずれの式 でも判別境界は 0 と定め, 判別得点が正の值をとるか， 負の值をとるかれより，何れの群に属するかが決定さ れるように作成した。な和，（）内の常数項は事前 確率 (3 群の来院頻度の比の対数) でめつて, これを 計算に加劣るべきか否かね，後に検討する。

\section{III 成績}

1. 判別関数作成の資料とした症例の判別成績 まず，事前確率を蒋虑しない場合について述べる。 判別関数に個々の計測値を代入して得られた得点の 分布は, 図1の如くで离っ。F1 の正常群纪预いて, (+) の得点示したのは正解例，（一）の得点を示し たのは誤認例であり，高血圧群に括いてはその反対で ある。F2，F3 亿ついても同様である。

その誤認率は, F 1 式化て正常 4/30 (13.3\%), 高 血圧 12/47 (25.5\%), F 2 式化て正常 1/30 (3.3\%), 大動脈弁閉鎖不全 2/19 (10.5\%), F 3 式飞ては高血 圧 $8 / 47(17 \%)$, 大動脈分閉鎖 不全 4/19 (21\%) であ つた。

次矤息の頻度を考虑する常数項（すなわち事前確 率）を加光るべきか否かを検討するに，これを加算し た場合，その誤認率はF1 式江て正常 7/30 (23.3\%),

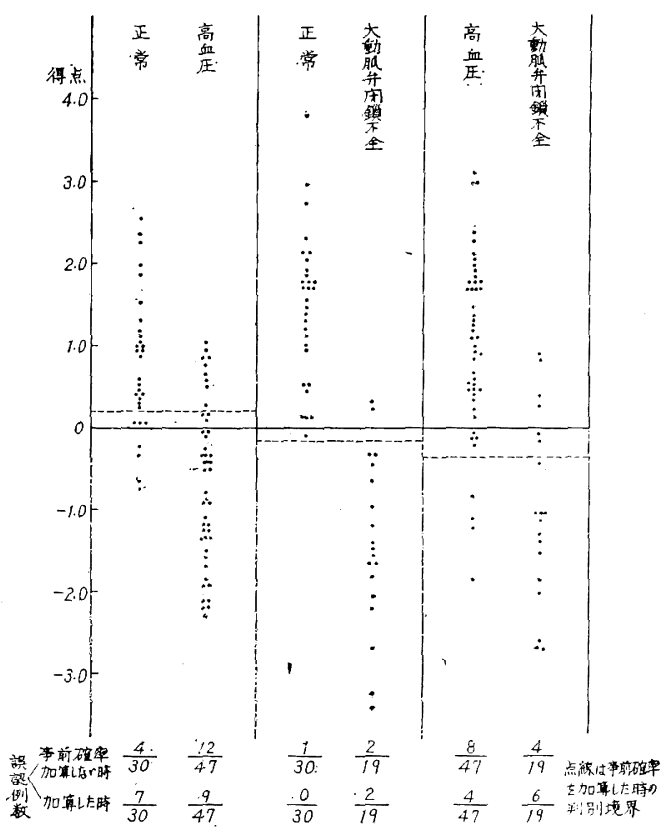

図 1 判別関数による各群の得点

高血圧 $9 / 47$ (19.7\%), F2 式飞て正常 0/30 (0\%), 大動脈弁閉鎖不全 2/19 (10.5\%)，F3 式にては高血 圧 $4 / 47(8.5 \%)$, 大動脈我閉鎖不全 $6 / 19(31.5 \%)$ で あつた。すなわち，事前確率を考慮した場合，之の誤 認率は事前確率奨慮しない場合飞比して, 高血圧で は低下゙の，正常上大動脈并関鎖不全ではもしろ增大の 傾向を示した。図1の点線は, 事前確率を考烱した際 の判別境界である。

2. 判別関数作成の資料としなかつた症例の判別成 
績

次に判別関数作成の資料以外の症例の計測值を各判 別関数に代入乙，その判別成續をしらべた。

その誤認率は, F 1 式にて正常 $2 / 20(10 \%)$, 高血 圧 $6 / 20(30 \%), F 2$ 式飞て正常 $3 / 20(15 \%)$, 大動脈 弁閉鎖不全 6/15 (40\%)，F3 式にては高血圧 11/20 (55)，大動脈弁閉鎖不全 $7 / 15(46.6 \%)$ であつた。す なわち，これらの判別成績は，さきの判別関数作成の 資料とした症例のそれに比してかなり低下する傾向が みられた。

このことは，著者の作成した判別関数が，母集団の ごく一部を対象としたのにすぎないことからみて，当 然であり，判別関数作成の資料とする症例数が多くな ればなるほど，この判別成績が上昇することはいうま でもない。

IV 各計測項目が判別に寄与する程度の検討

次に，各群の判別に，各計測項目がそれぞれどの程 度に強く影嘅しているかについてしらべた。実際の計 測值を代入した式について考えるに，大きな変動を示 寸項目注ど得点に大きく影響するし，一方，得点に高 い相関交有する項目もまた，判別に大きく影響を与え ると考允られる。

変動の大きさの指標としては, 実際の計測值を代入 した判別関数の各項の標準偏差を用い, この值と, 各 項の計測值と判別得点との相関係数との 2 つの値よ

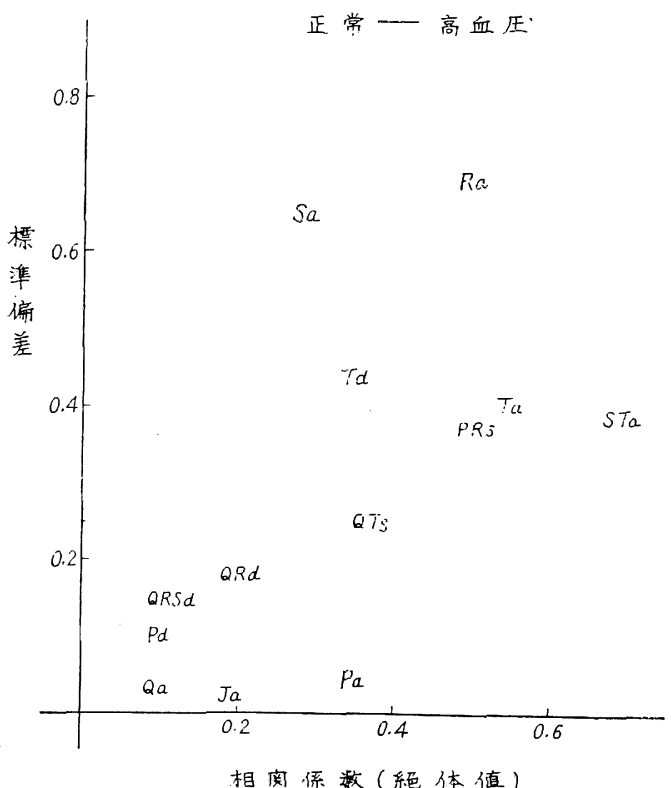

図 2 各所見が判別に寄与する程度
表 6 判別式の各項が判別に害与する程度

\begin{tabular}{|c|c|c|c|c|c|c|c|}
\hline & & \multicolumn{2}{|c|}{$\begin{array}{c}F_{1} \\
\text { 正常一高血生 }\end{array}$} & \multicolumn{2}{|c|}{ 正常-A I } & \multicolumn{2}{|c|}{$\stackrel{F_{3}}{\text { 高血圧 }}-\mathrm{A} I$} \\
\hline & & $\begin{array}{l}\text { 標集 } \\
\text { 偏痓 }\end{array}$ & \begin{tabular}{|l|} 
相閵 \\
数
\end{tabular} & $\begin{array}{l}\text { 䄚漼 } \\
\text { 偏差考 }\end{array}$ & \begin{tabular}{|l|} 
相閶 \\
偻数
\end{tabular} & \begin{tabular}{|l|} 
標淮 \\
偏差
\end{tabular} & $\begin{array}{l}\text { 睏閶 } \\
\text { 数数 }\end{array}$ \\
\hline \multirow{3}{*}{ 波 } & $\mathrm{Pa}$ & 0.003 & -0.33 & 0.495 & 0.28 & 0.239 & 0.10 \\
\hline & Qa & 0.098 & -0.04 & 0.404 & 0.21 & 0.333 & 0.26 \\
\hline & $\mathrm{R}$ & 0.723 & 0.47 & 0.535 & 0.37 & 0.519 & 0.05 \\
\hline \multirow[t]{2}{*}{ 高 } & Sa & 0.656 & 0.27 & 0.342 & 0.18 & 0.026 & 0.03 \\
\hline & $\mathrm{Ta}$ & 0.403 & 0.57 & 1.007 & 0.62 & 0.660 & 0.39 , \\
\hline \multirow[t]{2}{*}{ 值 } & $\mathrm{J}$ & 0.060 & 0.18 & 0.368 & 0.01 & 0.699 & 0.15 \\
\hline & $\mathrm{STa}$ & 0.397 & 0.68 & 0.414 & 0.27 & 0.359 & -0.08 \\
\hline \multirow{4}{*}{$\begin{array}{l}\text { 時 } \\
\text { 間 }\end{array}$} & $\mathrm{P}$ & 0.109 & -0.11 & 0.101 & 0.36 & 0.353 & 0.49 \\
\hline & QTSd & 0.158 & 0.12 & 0.024 & 0.10 & 0.174 & 0.57 \\
\hline & QRd & 0.198 & 0.21 & 0.165 & -0.41 & 0.646 & ) 0.20 \\
\hline & $\mathrm{Td}$ & 0.431 & 0.33 & 0.028 & -0.30 & 0.117 & -0.26 \\
\hline \multirow[t]{2}{*}{ 値 } & $\mathrm{PR}$ & 0.364 & .050 & 0.395 & 0.35 & 0.906 & 0.30 \\
\hline & QTs & 0.260 & 0.36 & 0.381 & 0.57 & 0.194 & 0.41 . \\
\hline
\end{tabular}

り，各項目が得点に寄与多程度を検討した。両方の 值の大きなるのほど，判別に大きな影猳を与えると考 壳らる。

これらの計算結果は表 6 の如くであり，F1 式，F 2 式，F3 式に机ける成績をそれぞれ図 2，3，4 亿 示す。縦蟿に变曛を，横軸飞相関走とつた。

この結果よりみると, 正常と高血圧の判別にはRの高 さ, 次いで ST 偏位度, $\mathrm{T}$ の高さ, $\mathrm{S}$ の深さ, $\mathrm{P}$ の 終りより QRSの始めまでの時間などの項目が大きく 正常一大動脈弁䦥鎖不全

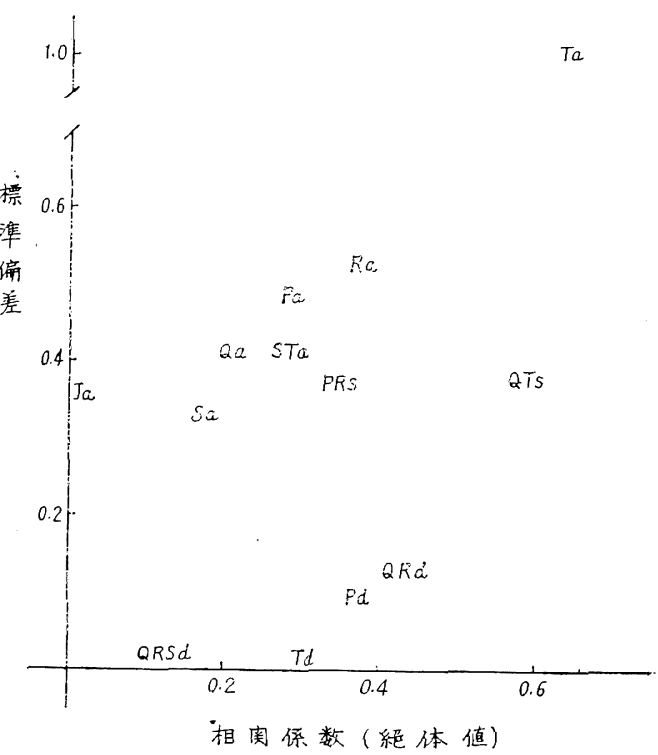

図 3 各所与が判別に寄与する程度 


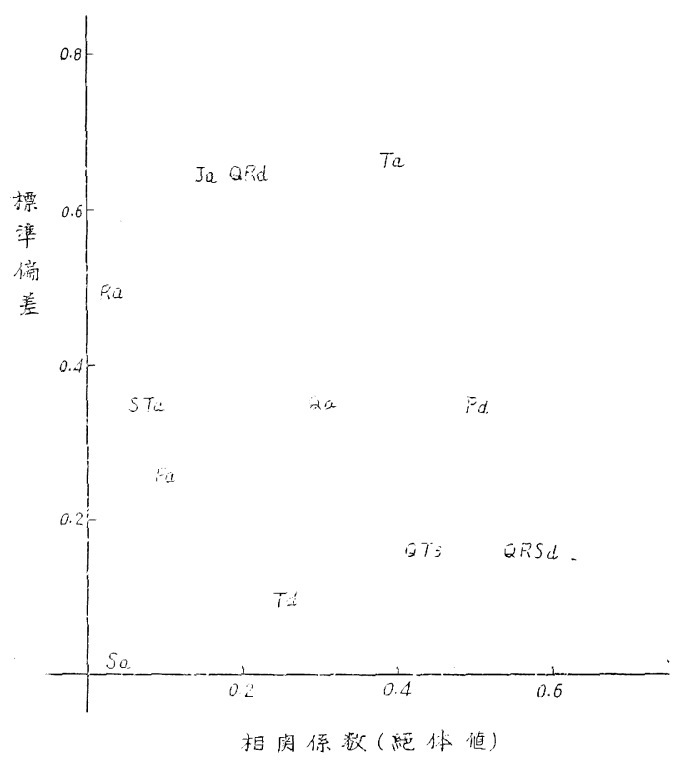

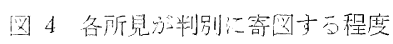
高血在一大動脈我閉鎖不全

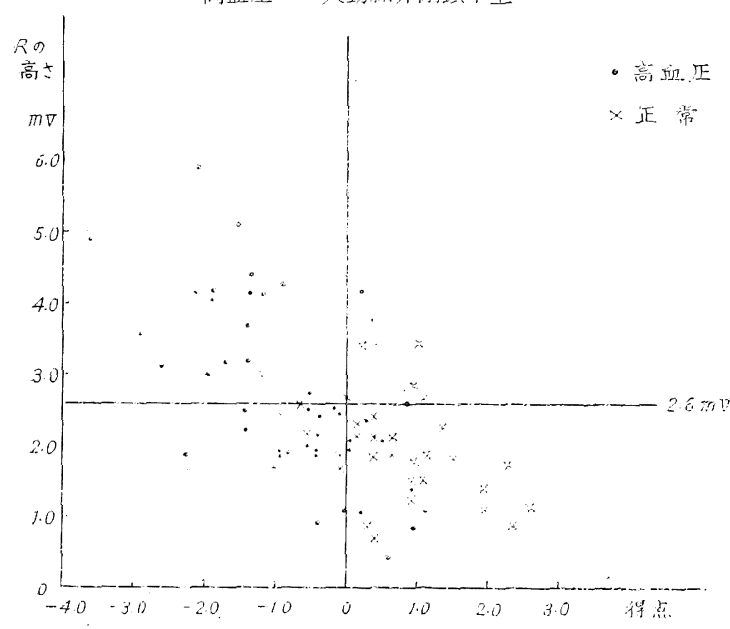

図 5 の高点と得点の囬倸

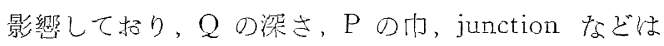
判別《あまり笴与しなかつたと判断される。

正常と大動脈升閉鎖不全の判別に大きく影㗽したの は、ます十の高き, 次いで QRS の終りから T の 始めまでの時間， Rの高さ，Pの高さ，Pの終りから QRS の始めまでの時間, ST 偤位度などであり, QRS の门，Tの门，junctionなどは判別に素り役 立たなわつたとみなされる。

高血压と大動脈弁開鎖不全の判別に際しては，Pの 終りよりQRS の始めまでの時間, T の高さ, junc- tion, 近接効果 ( $\mathrm{QRd}$ ), $\mathrm{P}$ の巾などが強く影響し, $\mathrm{R}$ の高さ, ST 偏位度などはその影鄉が弱いと判断され た。

\section{$\mathrm{V}$ 考察}

1. 対象症例の壳らび方について

判別関数による心電図判読を試みた諸家の報告をみ るに，その対象症例の選び方には，2雨りの方式がみ られる。その1は, 典型的な心電図パタンを呈する症

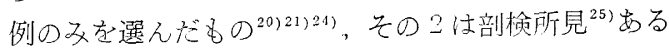

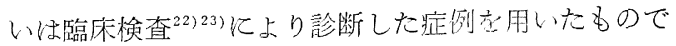
心電図所見にはとらわれないものである。

1 の方式は，現在用いられている猃徼基渠用いて たと光ば助型的な左室肥大心電図症例を劣らび，これ を資料として判別関数を作成したものでむる。かくし て作成された判別関数を用いて左宝肥大と正常の判別 を行なうことになるが、これはいわば、現在の䛦断基

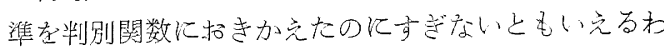
けで，現在我々が行なつている判読能力以上のものが 得られるとは期待しがたい。やはり理想的には, 剖検に上り左室肥大の確認された症例堂用い, こ れ起資料として判別閝数を作成するべきである 万。

判別閣数に上り直接病名を求めた垠告の中江も Iの方式にて症例学選択したものがある。市なわ ち, Rikli $5^{20)}$ の高血圧と大動脈并闒鎖不全の鑑 別は, Sokolovの左室肥大骖断基华に䔎合した症 例について行なわれたものであるが、この両疾患 に招ける循環動態の差を考兑れば，雨者に対して

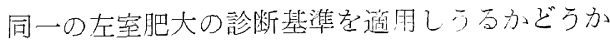
問題がある。この場合にも, 剖検に上り婷断の確 定された症例を，資料として朋いることがより罗 当であると若えられる。

一方、臨床上の現笑問題としては、病勢の完成 、していない時期の症例走も骖断せ孙ばならない場 合がすくなくなっこの意味からいうと、剖娭例のみ

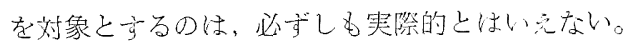

著者は本研究にあたり，心電図所見上り，高血压あ るいは大動脈戈閉鎖不全という病名立直接求めること

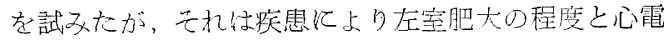
図所見の関係に差のあることを惹慮したためであり， かつ奏際的有用性を考え，心電図所見のまた具型的で ない症例をふくめて，判別関数作成の資料とした。

2. 諸家の作成女る判別関数の批判

Rikli $5^{20}$ は, 正常, 高血圧性左空肥大, 大動脈弁 
閉鎖不全による左室肥大の 3 群につ当, $V_{5}$ 誘 導のみ の 12 項目を用以, そのうちの1つの群と他の 2 群を 合わせたもの(たとえば高血圧と正常十大動脈弁閉鎖 不全）を判別する 3 個の判別関数を作成した。これに 対し，著者の方式は Rikli らと同じ疾思を対象とす るが，用いた所見の数は 13 個であり，かつ 3 群のう ち 2 群間を判別する 3 個の判別関数を作成した。その 際, 残りの 1 群は判別から除外される。

1 個の判別関数で 2 群間の及を判別する方式と，1 群と他の 2 群を判別する方式のいずれが有利かについ ては，にわか解答できないが，この場合，両方式を 併用すれば更に有利でもるとも思われる。すなわち， まず 1 個の判別関数で正常と 2 疾患群を判別し, 次の 1 個の式で疾㭧群間を判別すれば，結局 2 個の判別関 数にて 3 群が判別されたことになる。

次に岡島, 安井 $5^{21)}$ は, 正常, 左室肥大, 右室肥大 の判別に, Frank 法を用いた X, Y, Z 軸誘導のQRS から $10 \mathrm{msec}$ 招きの 8 点をとり，それに $\mathrm{T}$ 波の頂点 を加えた計 9 個，3 誘導で合計 27 個のバラメータを 用い， 2 群間のみを判別する 3 個の判別関数を作成し た。な技彼等はその後, ST 部分の 6 点のふれも加克 た計 45 個のパラメータによる判別関数子作成してい る ${ }^{31)}$ 。う際，彼等は各計測項目の正規分布性の有無 については全然検討定行なつていないが, その理由と してこの検討支あまり郒格に行なうと，本来の情報が 失なわれる扔それがあるからだとしている。

しかし, 判別関数出, 計測值が多次元の正規分布を なしている場合に腩用されうるというのが良来の洘光 方であつて，計測值が正規分布を示さない時には，何 らかの方法によりこれを正規型に変換寸る必要がある

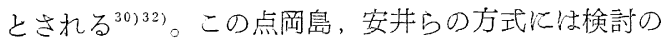
余地があると思われる。

ただし, 統計学者の中にも, 判別関数は必ずしも多 次元正規分布の場合のみでなく，他の分布を示寸場合 飞適用しても原理的に䛊りはないとの立場をとるもの 孔いる ${ }^{33)}$ 寸なおち、判別閔数作成にあたつて, 計測 值の正嫢分布性を重視することには暴論も岁るわけで ，将来な㕲検討されねばなら双ところである。

な招 Caceres ら ${ }^{22)}$ は, 肺動脈狭窄と動脈管開存の 鑑別飞, P 軸, QRS 軸, T 軸ならび飞 QRS, STT, P-P, P の時間值の 7 項目を用いて判別関数を作 成している。

以上述べて方式では，笑測值がそのまま用いられて いるが，次のような方式を陚みた研究もある。
Cady $5^{21}$ 依, 正常と左室肥大につき SVEC III 法 の $\mathrm{X}$ 誘導について $7 \mathrm{msec}$ 每の 100 点をとり,こ れをまず 34 項のFourier 級数に懝開し，その係数 のうち両群間で有意差の認められた項のみ暻び，そ れら上り判別関数走作成した。この方式は, Fourier 級数と判別関数の 2 つ数学的方法寺たく文に組文合

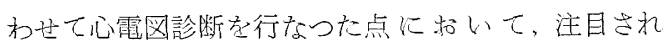
る。

一方，Rees $5^{25}$ は，基礎疾想として肺突息在有す る212名の炭坑夫につき, その剖検所見によりこれら を肺性心群，冠動脈聅思群，雨者の合併群，扣よび雨 者ともなかつた群の 4 群に分類したのち, これらの群 を心電図のみから改めて鑑別しょらと試み，判別関数 を用いた。

まず，肺性心抢よび冠動脈疾息のそれぞれに対する 12 誘導心電図に上る彭断規準 (2 分注括よび 3 分法) を設定し，上記 4 群の心電図がこの骖断基準に合致す る百分率をしらべ，高い值を示す 19 個の項目を党ら んだ。次いでこれら 19 項目と年令孝加党た計 20 項 目より, latent root 定計算して、4群を同 時に判別 するための 2 個の判別関数孝作成した。 4 群相互間を 最子良く判別させる判別境界の設置は, 各群冬症例の データをこの2つの判別関数に比入して得られた各々 2つの判別得点を, 便宜上平面図上にプロットして行 なつている。

ただし彼等は, 判別関数作成にあたつて实測值（連 続量）卆用いず，離散量を用いている。先に存述べた 如く, 判別関数が腩用されるのは, 多次元正規分布を なす連続量の場合であり，この立場よりすれば，離散 量を用いることは, 判別関数を近似的に利用したにす

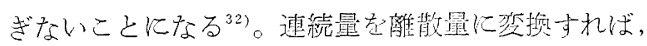
本来の情報量が減少し, その結果疾息判別には不利と なることはいうまでもない。ただし碓散量を用いれ ば、判別関数作成の計算量がかなり節約できるという 利点は岁る。

いずれにせよ，連続量と離散量のどちらを用いた時 が有利かは, 同じ対象につき, 雨者それぞれによる判

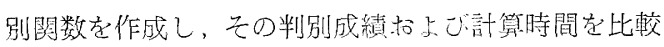
してのちに判断ずべきである。

この Rees らの方式では，4群ぶいわ斿同時に判別 されるが，このように，3群以上在同時に判別する方 式は, Rao ら ${ }^{27}$ に上りすでに2・3試多られている。 心電図の自動判読のためには, 多くの突息局時に分 類できる方式が望ましいから, 将来 Rees らの如き試 
$-46-(86)$

みが採用される可能性もある。

以上, 热家の方式の各々につき若千の批判を加光た が，諸家の方式を総括してみると，1つの問題か残 る。すな加ち心電图存従来心電図学的に意味がつけら れなかつた非常に細かい点まで経時的に計測し，それ らの值の全てを利用して判別関数を作成する方式 ${ }^{21) 24}$ と，意味がありそうな荒い区分点の計測值のみを利用 する方式 ${ }^{20122123251}$ との䞠劣である。

前者の方式では，今までかえりみられなかつた新し い情報が得られる可能性もあり, 判別成績も後者飞比 して良いであろうが，反面，無䭾な情報をも多く含み 計算量も龙大となる。後者ではこれと逆のことがい光 る。将来大型計算機が手愺に使用できるようになれ ば，前者の方式を採用することも考元られるが，現段 階に拾いては、焉らかじめ医師が経験的に判別に役立 ちそうな項目を選んで，これらより判別関数を作成し た方が, 計算量を減らすという意味からいつて貿明で あるかもしれない。

3. 著者の判別関数について

著者は，高血圧，大動脈升閉鎖不全および正常対照 の3 群相互間の判别関数作成にあたり， $V_{5}$ 誘導に扣 ける 13 個の計测值をその妾ま用い, かつ典型例の久 ならず軽症例をる含ませた。

その理由は, 次の如くである。

(a) 高血圧と大動脈弁閉鎖不全结同じく左室肥大 心電図を特徴とするが，両者に括ける循璝動態の 差より又て，画一的な左室肥大診断基準を適用す るのは妥当でないと考党られる。そのためには， Sokolov \& Lyon $5^{10)}$, 森ら ${ }^{12)}$, その他による 診断基準に打けるが如き限界值による判断では充 分でなく，各計测㲘にそれぞれ適当な重みつけを 行なつて, 用いるのが妥当である。

(b) 一誘導につき考えられるすべての值として， 表1の13 個を対泉としたが，去のなかにはこれ まで情報源として用いられなかつたものもある。 しかし，この際もう一度その佂値の检討をこころ み、もし意義を有するものなら採用しようと考光 た。ただし計算量が多大となるので，左室に関す る情報を最も充分らくむとされる $V_{5}$ 誘導のみを 対象とした。

(c) 半別関数作成資料として最も正確なのは剖検 例であるが，我々はごく初期の例在も日常骖断の 対象とすることがすくなくない。それ故，奏際問 題を考虑し，まだ心電図所見の完成されない例を
もふくめて, 資料とした。

(d) 判別関数作成にあたり事前確率をも考慮すべ きか否かの問題がある。それ故これを含めた場合 としからざる場合の両方を計算した。

4. 著者の判別関数による判別成績について

(a) 判別関数作成資料とした症例の判別成績 判別成續の項（図1）で述べたように，事前確 率を考慮しない場合の成績は用いた誘導が $V_{5}$ の みであつたこと，また対象とした症例が必ずしも 典型的なるののみではなかつたことを考虑すれ ば，著者が期待した以上の良い成果であつた。

ことに, 共に左室肥大の傾向を有し, 従来心電 図のみからでは判別不能とされていた高血圧と大 動脈弁閉鎖不全の判別について, 満足すべき結果 が得られたことは意義がある。また，これらの成 續は, 臨床像が十分完成されていない時期に招い てもすでに多数の情報が心霞図に含まれているこ とを示唆する。

著者と同様の対象に判別関数を用いた Rikli $ら^{20)}$ も, 医師が肉眼でははとんど判別不能に近い 左室肥大群の判別に, 予想以上の好成績を光たと 述べている。また Ress ら ${ }^{25}$ の如く，臨床的にも 鑑別がかなり困難と考光られる 4 群が心電図所見 のみを用いた判別関数によりかなり優秀に判別さ れたと述心゙ている報告もある。

したがつて，判別関数の利朋は，心電図䛦断に すぐれた 1 つ方式を与えると考えられるが，そ の判別成績を一層向上させる必要があるう。その ためには, 更にすぐれた数学的方式の開発がのぞ まれる。

事前確率を加光た時, 高血瓜の俁認率は低下 乙, 正常と大動脈弁閉鎖不全は増大傾向を示し た。その理由は, 高血圧症例の来院頻度が他の 2 群に比して高かつたことによるためと思われる。 この結果よりみると, 事前確率を加えた時には, 来院頻度の高い疾腎はより良く判別されるが，こ れに反し，来院頻度の低い矮息は見落される危険 のあることが示唆される。

心電図診断に判別関数を試みたいままでの報告 では, 事前確率の問題はまつたく無視されている ように思われる。しかし, $\mathrm{RaO}^{27)}$ は, 判別関数作 成の際, も乙事前確率が明らかである場合には, これを加党るのが，統計学的には正しいとしてい る。一方, 一般的に云光ば事前確率そのものは綮 
密には未知であるとの意見も紹介されて招介 ${ }^{33)}$, また医学的見地から，事前確率を強調しすぎる

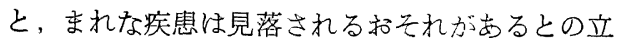
場をとるものもあり ${ }^{34)}$, 現在のところ決定的結論 は示されていない。

我々が心電図をながめて左室肥大があるかない かを判断する時の思考過程のうごきを反省する と, 事前確率すなわち左室肥大の頻度はほとんど 考慮に入れていない上うに思われる。このことを 考劣ると，事前確率を含ませない结うが，我々の 診断論理飞合うのかもしれない。この問題は，今 後統計学的に充分検討される必要が离ると考兄 る。

(b) 判別関数作成の資料としなかつた症例の判別 成續関乙て

判別関数作成の資料としなかつた症例の計測值 を判別関数に代入乙た成績は, 正常之疾患の判別 については必ずしも悪くはなかったが, 筷㭧群間 の判別はかなり低下した。その理由は,資料とした 大動脈弁閉鎖不全例の数が少ないため, 計測值が かなりかたよっていたことによると推測される。

この問題は対象例の数をふやすことにより次第 に解決される。電子計算機隹対し, 症例が 1 例ふ 壳るごとに計算をしな扔して新しい判別関数を作 る上万命令して招けば, 判別関数は自動的飞改善 され，判別能力は扔のずから向上するであるう。

5. 判別関数の各項目が判別汇寄与する程度につい $\tau$

\section{(a) 判別寄与程度の判定法の検討}

著者の用いた 13 個の計測值のうち, 判別反重 要な意味を有するものもあり，ほとんど価值のな いものもあると考光られる。計算量の節約のため には，後者を省略することが考党られる。一方， 臨床的の問題からいうと, 疾患の判別に有効項目 を兄らび出し，それらと各疾患の循環動態の特徴 とを対応させることは，重要な意義を有する。

この意味で, 各項目がどの程度に判別得点に影 響しているかの検討を行なつた。しかし現在では これを知る決定的手段は, 統計学的にも見出され ていない。この問題に対する解決法の一つとし て, $n$ 項よりなる判別関数がある場合, 1 項ずつ ぬいて $n-1$ 項の判別関数を $n$ 回作成し, 各々の 判別成績を比較することが考えられるが，その実 行は電子計算機を利用しても，はなはだ非能率的
である。

著者はこの問題に関し, 比較的簡単な計算より 求められる值, すなわち標準偏差と相関係数の 2 つより検討を行なつたが，類似の問題以対する他 の研究者の行なつた解析法を参照すると，三好 ${ }^{30)}$ は肝疾患群と非肝筷㭧群の鑑別のため作成した 12 項目のうちから重要な項目 3 種を党らぶのに際し Mahalanobis の汎距離付相当する数值 $\Sigma$ bidi ( $b i=$ 各計測項目の判別係数, $d i=$ 両群での対応 する各計測量の差のベクトル）の構成成分 bidi を用い，その大きな值をとる項目ほど判別に重要 とみなした。

Caceres $ら^{22}$ は, 用いた 7 項目の中, 2 項目 ( $T$ 軸, QRS 軸) の F test 值が他の項目飞比 乙非常に大きく, かっその P-valne が 0.01 以下 であるのに対し.他の項目では 0.05 以上であっ たことより，この 2 項を選んだとしている。

また，長尾ら ${ }^{35}$ が高血圧集団検診のため作成し た判別関数では, データを正規化した上で求めた 判別係数に相当する值（絶対的重みと名つ计た） を比較する方法が用いられているが，この方法 は, 結果的には著者が計測值を代入した各項の標 準偏差を求めた方式とひとしい。な报，彼等に上 れば, この絶対的な重みと, 医師が経験的に兄て いる重みとは必ずしも一致しなかつたが，その理 由は, 判別係数作成の計算過程から推測されるよ う飞, 判別係数の大小が, 阡測值間平均值招よび 分散の差によつてのみ定まるものではなく, 各計 測項目間の相関の大小片ってる左右されるため と考党られる。例党ば 2 群間の平均值の差が大 で，分散が小なる計測值がある場合，医師は当然 この計測項目が判別に重要と考克るであるろが， しかしこの項目と他の項目との相関が非常に高い 場合には・この項目の判別係数は小さな值を示す ことがありうる。この意味から，この絶対的重 み, あるい著者の求めた標準偏差のみを用いて 判別飞寄与する程度を断定することは，いくらか の危険を伴う。

そこで，著者は計測值と判別得点の相関係数を あ求め, これと計測值を代入した判別関数各項の 標準偏差の 2 つり，この問題を評価した。この 際, 判別得点がそれぞれの計測項目の変動と独立 的でないことから，単なる相関係数よりる，偏回 州係数を求めた方が妥当かもしれないという疑問 
$-48-(88)$

がある。しかし、ひとたび得られた判別得点は， 疾患の判別という独自の機能をもつ因子とみなす こともでき, この場合には個々の計測値とは互い に独立的であるとみなされる。したがって，この 意味から雨因子の相関関係を求めることは数学的 记も正しいとい方る。

(b) 各群の判別に大きく奇与寸る計測項目につい $\tau$

i ）正常と高血圧の判別について

先に述ベた如く, 両群の判別には R の高さ, $\mathrm{ST}$ 偏位度, T の高さ, S の深さ, P の終り から QRS の始めまでの時間などが大いに寄与 しているものとみなされる。これらの項目のう ち， R の高さ ST 偏位， T の高さは従来用い られている左室肥大心電図の $V_{5}$ に関寸る診断 基準に採用されているところである。

Sokolov \& Lyon の左室肥大心電図診断基 準では， $V_{5}$ の $\mathrm{R}$ が $2.6 \mathrm{mV}$ 以上であること が重要視されるのは，周知のごとくである。そ こでこれら 2 群について $\mathrm{R}$ の高さと判別得点 の関係について調ベたところ, 図 5 に示す様に 高血圧で $V_{5}$ の $\mathrm{R}$ が $2.6 \mathrm{mV}$ に達しなかつ た症例でも，大部分はやはり高血圧と診断され た。一方, 正常例で, $\mathrm{R}$ が $2.6 \mathrm{mV}$ 以上であ つたものでも, その大多数はやはり正常と判定 された。

これらの成續は， $V_{5} の \mathrm{R}$ の高さ以外の情 報がかなり重要な役割を演じていることを示唆 するととるに， R の高さのみより左室肥大の 診断を行なうことの危険性を警告する。な招 $\mathrm{P}$ の終りから QRS の始めまでの時間が両群の判 別にかなり重要な意味を有することは今日まで 何人によつても指摘されて招らず, 著者にとつ ても意外な成績であつた。

ii）正常と大動脈并閉鎖不全の判別について この場合には，Tの高さ, ST 時間 (QTS), $\mathrm{R}$ の高さ, $\mathrm{P}$ の高さ, $\mathrm{P}$ の終りから QRS の 始めまでの時間などが, 判別に強く笴与してい るとの成績がえられた。

大動脈弁閉鎖不全屾, 高血圧と同様左室肥大 を特徽とする疾患であるのに，正常との判別に 際し高血圧とはいささか態度を異にしているこ とは注目に值する。ことに大動脈弁閉鎖不全に 招いては，かなりの情報が $\mathrm{P}$ 棘にふくまれてい
ることが示された。

iii）高血圧と大動脈并関鎖不全の判別について 両疾患ともに左室肥大心電図を特徵とするこ

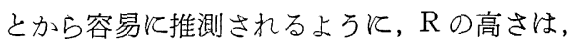
㭱とんど役立たず，P の終りよりQRS の始め までの時間, T の高さ, junction, 近接効果 (QRd)，P の巾などが判別に大きな影響を与え た。

やはり，ここでも大動脈弁開鎖不全の心電図 にはPに関する情報が多く含まれていることが 示陖されたが, これらの情報は從来これら疾患 を判別する祭の心電図判読論理として,さほど 重要とはみなされていなかつたものである。た だし，これらの計測値が涘両患の病態生理学的 な差異に関し、いかなる関係をもつているかは 簡単には決定しがたい。

著者と同様の疾患群間の判別を試みた Rikli らは, 判別飞寄与寸る項目について特別の検討 を行なつていないが，2 群間の計測值の有意差 を検定した結果，用いた所見のほとんどが判別 に有効なるのであるうと述べている。

6. 心電図判読論理の問類点と将来

最後に, 判別関数もらくめて現在行なわれているい くつかの心電図判読に関する研究について若干考察を 試み，それらにもとづき心電図判読の将来について私 見を述べだい。

判別関数による心電図判読については, 本論文に示 すと扣り，類似のパタンを呈する祑患群の判別にもき わめて有效であり，また多数の聅患群の判別を同時に 行ないろる可能性子示唆された。

しかし, 判別関数作成の際の数学的条件 (正規分布 性, 事前確率など) あるいは判別に有効な項目の選定 など、な捦討されればなら問題が残されている。 更に, 判別関数により判別された疾患には，いずれの 群かに属するかという判定が与光られるのみで, 他の 群汇属するかもしれぬという確率的な考慮が払われて いない。

この点, 疾患の頻度 (事前確率) 抢よび咨患に括け る症状の発現頻度をもとにした Bayes の定理を用い た木村ら ${ }^{17}$ の心電図判読法では, 個々の症例の診断に 確率的な意味をもたらすことができる。な沶，事前確 率を用いた時, 稀な疾㭧が見落される可能性のあるこ とを考慮して, 彼等は事前確率を考慮しない尤度を用 いた検討 ${ }^{19)}$ 行なつているが，その成續は Bayes の 
定理のそれとはとんど差異がなかつたとのべている。 ただこの方式の短所は，実測值を用いず，yes一no 方式で所見の有無を決定するため，情報がそこなかれ る可能性のあること, また, 所見の有無の限界值の大 きさにより最終的な診断も異なつてくることである。

Stark, 岡島ら (3) $^{4}$ とり試みられた multiple adaptive matched filter 法は, 心電図パタンを相互相関 係数に上り連続的に細かく分類する方式で,きわめて すぐれた着眼点を有するが, 計算量が龙大であり, 疾 患の判別にまではまだ十分応用されるにいたつていな い。

現在, 試みられているこれらの方式の長所を総合し て, 多数の疾㭧を能率的かつ正確に判別する方式が将 来開発されることが期待される。しかるのち，すでに ほとんど実現されている自動計測法と結合され，心電 図誩断の完全な自動化が実用となるであるう。

\section{VI 結論}

心電図診断に括ける判別関数の利用価值を, 臨床的 飞重要視される左室肥大, すなわち高血圧招上び大動 眽弁開鎖不全をえらんで検討した。

（1）臨床所見より診断した高血圧 47 例, 大動脈 弁閉鎖不全 19 例括上び正常 30 例を対象とし, $V_{5}$ 誘導のみの 13 個の所見の計測值を用い, 電 子計算機 IBM 7090 により, 各 2 群間を判別す る判別関数を作成した。

(2) 事前確率老考虑しない場合の誤認率は, 各群 により異なるが，3.3\%ないし 25.5\%であつた。

(3) 従来心電図のみからでは判別不能とされた高 血圧と大動脈弁閉鎖不全についても，67\%が正 しく判別された。

（4）事前確率を考虑した場合，高血圧飞関寸る判 別成績は，これを考虑しなかつた場合に比し向上 したが，大動脈弁閉鎖不全については低下した。 この結果は, 事前確率を考慮した際には, 頻度の 少ない祑患を誤判しやすいことを示す。

（5）判别関数作成の資料としなかつた症例につい ての判別成績は，かなり悪かったが，今後に抽け る資料の增加に上り改善されるであるう。

(6) 判別関数の各項が判別に寄与寸る程度をしら べるため, 各項の変動と, 各計測值と判別得点の

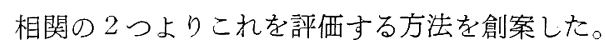

(7) 正常と高血圧の判別々は, R の高さ, ST 偏 位度, $\mathrm{T}$ の高さ, $\mathrm{S}$ の深さ, $\mathrm{P}$ の終りょり $\mathrm{QRS}$ の始めまでの時間が大きな意義を有した。最後の
項目は，従来何人によっても注目されなかつたと ころである。

（8）正常と大動脈弁閉鎖不全の判別には，Tの高 さ, $\mathrm{ST}$ 時間, $\mathrm{R}$ の高さ, $\mathrm{P}$ の高さ, $\mathrm{P}$ の終り よりQ RS の始めまでの時間などが強く笴与して いることが示された。最後の 2 項目はやはり従来 注目されていなかつたところである。

（9）高血圧と大動脈弁閉鎖不全の判別では，Rの 高さは役立たず，P の終りょり QRS の始まで の時間, $\mathrm{T}$ の高さ, junction, 近接効果, $\mathrm{P}$ の巾 などが大きく影響を与えるとみなされた。

(10) Sokolov \& Lyon の左室肥大診断基準とく らべるに， $V_{5}$ の R が $2.6 \mathrm{mV}$ に澾しない高血 圧でも，判別関数に上れば大部分が高血圧と診断 され， $\mathrm{V}_{5}$ の Rが $2.6 \mathrm{mV}$ 以上ある正常例でも， その大部分はやはり正常と判定された。

（11）以上の成績上り，判別関数は心電図判読にき わめて有用な一方式であると結論された。

本研究における判別関数作成にあたつては, 青山学院大学 理学部二宮理慧譜師の指導と協力をいただいた。宗た，文部 省統計数理研究所, 林知已夫部長ならびに雨宫多賀子氏の助言 と教示をいただいた。ここに上記諸氏に厚く感謝する。

\section{文献}

1) Stallman, F.W. et al. : Cirulation Research., 9, 1138 (1961)

2) Pipberger, H.V. : Circulation Research., 11, 555 (1962)

3) Okajima, M. et al. : Quaterly Progress Report, Research Labaratory of Electronics. MIT., 65 (1962)

4) Stark, L. et al. : Communications of ACM., 5 : 527, (1962)

5) Steinberg, C.A. : IRE Transactions BME-9, 23 (1962)

6) Caceres, A.C. et al : Ciarculation., 25, 356 (1962)

7) 木村栄一, 他: 医用電子と生体工学 3, 29 (1965)

8) 闵藤正男, 他: 計測自動制御学会第 3 回学術清演会, 126, (1964)

9) 坂本捷房, 他 : 計測自動制御学会, 第 3 回学術偝演会, 403, (1964)

10) Sokolov, M. et al. : Am. Heart J., 37, 161 (1949)

11) Scott, R.C. et al. : Circulation., 11, 89 (1955)

12）森 博愛，他：胸部疾患， 5, 1537 (1961)

13) Arbeit, S.R. et al. : Differential diagnosis of the electrocardiogram., (F.A. Davis Co. 1960)

14) 木村栄一：最新医学, 17, 794 (1962)

15) Kimura E. et al. : Jap. Heart J., 5, 212 (1964)

16) Young, T.Y. et al. : IEEE Transaction on BioMedical Eng., 3, 60 (1964)

17）木村栄一,他：日本臨床，20, 2293 (1962)

18) Kimura, E, et al : Jap. Heart J., 4, 469 (1963)

19）木村栄一, 他: 医学のあゆみ，51，255(1964) 
$-50-(90)$

20) Rikli,A.E. et al. : Ciarculation., 24, 643 (1961)

21) Cady,L. et al. : Circulation Research., 9, 1078 (1961)

22) Caceres A.C. : Ciarculation Research, 11, 563 (1962)

23）木村栄一, 他: 内科, 12, 98 (1963)

24）岡島光治, 他 : 医用電子と生体工学, 2, 14 (1964)

25) Rees, H.A. et al. : Brit. Heart J., 26, 233 (1964)

26) Fisher, R.A. : Statistical Methods for Research Workers., (Oliver \& Boyd. Ladon, 1950)

27) Rao, C.R. : Advanced Statistibal Method in Biometric Research., (John Wiley \& Sons, New
York. 1952)

28）北川敏男編：確率及び推計学の進歩, 岩波書店, 1953:

29) 鳥居敏雄, 他: 最新医学, 7, 35 (1952)

30) 三好栄一: 東京医誌, 4, 1 (1956)

31）安井昭二, 他：第 4 回 ME学会大会予稿集 125(1965)

32）鳥居敏雄, 他 : 医学・生物学のための推計学 (東大出 版会, 1961)

33）現代統計学大辞典 (中山伊知郎 編), (東洋経済新報社, 1962)

34）高橋晄正 : 医学のあゆ久, 51, 249 (1964)

35) 長尾透, 他: 総合医学, 20, 246 (1963)

(受付：1965 年6月 29 日) 